\title{
Mythical Motifs in the Furniture of Elamite Civilization
}

\author{
Neshat Madadi, ${ }^{1}$ Hassan Ali Pourmand ${ }^{2}$ \& Seyyedeh Motahareh Mousavi ${ }^{3}$ \\ ${ }^{1}$ Department of Public, Qazvin Branch, Islamic Azad University, Qazvin, Iran. \\ ${ }^{2}$ Associate Professor, Faculty of art $\mathcal{E}$ architecture, Tarbiat Modares University, Tehran, \\ Iran. \\ ${ }^{3}$ Department of Architecture, Faculty of Architecture and Urban Planning, Qazvin Branch, \\ Islamic Azad University, Qazvin, Iran. Email: motaharehmousavi@yahoo.com
}

\begin{abstract}
Elamites the first founders of the kingdom in Iranian territory were the pioneers of the use of animal motifs in the design of Iranian furniture. Since their very inception up to their decline, they made use of such motifs as snake, lion, wild goat and duck in designing their furniture. The current essay aims at the identification of the causes of the application, culmination, and decline of these motifs in designing furniture, particularly ancient Elamite thrones. The present study is fundamental research given its objective and is qualitative and exploratory in view of its essence. Data collection is based on library studies. The results show that in Elamite civilization due to the sacredness of snake, this mythic creature is the most popular motif in designing furniture. Elamites in addition to snake used such alternative motifs as lion, wild goat, and duck which enjoyed religious and social acceptability. Such motifs were used by Elamite gods, kings or officials in religious rituals or ceremonies and the reflection of Elamite ideas in relation to these creatures is visible in the design of their furniture.
\end{abstract}

Keywords: Iranian Furniture, Motif, Elamite Civilization.

\section{Introduction:}

The exhibition of animal forms in the design of furniture has been quite popular among ancient nations. In ancient Egypt, animal forms like ox, lion, wild goat, duck, viper, cockroach, and in Greece such animal forms as lion, ox, goat, eagle with lion body and winged cows were used in the throne, desk, chair etc. In ancient Persia, the use and exhibition of animal forms like snake, lion, wild goat, duck, cow, horse and eagle are also visible.

Elamites, the people who lived in the southwest of Iranian Plateau from fourth to first millennia $\mathrm{BC}$ were the founders of the use of animal forms and motifs in the design of Iranian furniture. They made use of mythical and religious animals at the top of which lied snake in order to design their furniture. Unfortunately, the furniture of Elamite civilization, their motifs and concepts have been poorly studied and identified and researches like the present one can provide the ground for the introduction and use of them in contemporary furniture designs in a modern way. In the present essay the authors for finding effective ideas in furniture design with motifs like snake, lion, wild goat and duck in Elamite civilization in addition to studying their symbolic notion throughout this civilization express the relationship between these concepts and Elamite furniture and the way in which these concepts have influenced the furniture design with these motifs in Elamite civilization.

(c) AesthetixMS 2020. This Open Access article is published under a Creative Commons Attribution Non-Commercial 4.o International License (http://creativecommons.org/licenses/by-nc/4.o/), which permits non-commercial re-use, distribution, and reproduction in any medium, provided the original work is properly cited. For citation use the DOI. For commercial re-use, please contact editor@rupkatha.com. 


\section{Methodology:}

The current study is fundamental research in view of its objective and is qualitative and exploratory because of its essence in which the method of grounded theory has been used. Data collection is done based on library studies. The statistical population includes the remanents of furniture of Elamite civilization with mythical motifs from the early emergence of Elamite civilization (fourth millennium BC) until the collapse of this civilization (first millennium BC).

\section{Research Background:}

Among the studies conducted concerning furniture of Elamite civilization one can refer to the following:

- In the chapter sixty-two of the book "A Review of Iranian Art" under the title of "Paraphernalia", M. Apten and Ackermann after a short introduction of ordinary Iranian paraphernalia proceed to study part of the paraphernalia of Iranian courts in PreAchaemenid, Achaemenid, Suluki, Parthian, Sassanid, early Islamic, Seljuqi, Teymurid, and Safavid cultures (Poppe, 2008: 3051-3058).

- In Esfandyari's article entitled "History of Chair and Water Lilly in Archaeological Documents" which has been prepared in two parts, in the first part the history of production and use of chair in ancient cultures of Middle East nations including Iran and West Asia in a short fashion (Esfandyari, 1998: 63-70). Rezaei in his article entitled "Internal Architecture in the Life of Ancient Iranians 1 and 2" has introduced examples of internal architecture and design of furniture during Elamite, Achaemenid, Parthian and Sassanid kingdoms (Rezaei, 2006: 16-20). The article entitled "Furniture of Ancient Persia (Thrones of Ancient Persia)" is research concerning the thrones of Ancient Iran. In this essay, Mousavi undertakes the identification and introduction of various types of these thrones and expression of their application in different rituals by various social classes (Mousavi, 2010: 171-179). In the MA thesis of Sajjadi entitled "Elamite Thrones from 300o640 BC", 152 remanents of Elamite thrones remained from 3000-640 BC on seals, reliefs, statues, and renowned Arjan Cup, have been studies. The results show that Elamite artists have taken advantage of three models for designing their thrones, i.e. 1- animal form, 2geometrical form, and 3- simple. This type of thrones was used in various religious and irreligious ceremonies by Elamites with different social degrees (Sajjadi, 2002).

\section{A Review of Snake Motif in Design of Elamite Furniture:}

Although the use of snake motif in the design of furniture is not merely limited to Iran and some examples of it can be seen in other ancient and contemporary civilizations worldwide, what is still of specific importance concerning this motif in Iranian furniture as compared to other civilizations is the old background of its use. The first samples of the use of this motif in the design of Iranian furniture are seen in Elamite civilization. If we consider the Elamite Koorangoon Relief to date back to $3500 \mathrm{BC}$, snake is the most ancient animal motif used in the design of furniture of Elamite Civilization and Iran. 


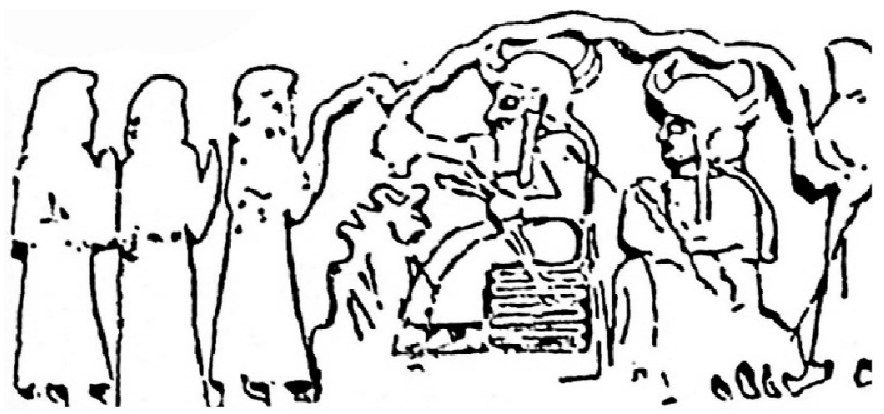

Image 1. Iran, Koorangoon Relief, and God on a Throne in the form of a Coiled Snake (source: Prada, 20o4: 82)

Furniture with snake motif has been used in this civilization simultaneous with the formation of belief and worship of snake among the Elamites, i.e. early days of the emergence of Elamite civilization (fourth millennium BC). In the second millennium simultaneous with the culmination of the belief in snake among them we are witness to the popularity of the use of this motif in the design of their furniture. But in the first millennium BC when this belief started to vanish, we rarely find any similar motif on the furniture.

Elamites considered snake to be a shield against the diabolic forces (1) (due to the eyes of snake) and a symbol of fertility (2) (due to the capability of skin changing and revival) and water (snake due to the flexible body it has reminds the twists and turns of the underground water routes insofar as Elamites declared the snake to be the god of underground effervescent waters). On the other hand, snake was considered to be a Keeteen (Elmaites believed that there are powerful mysterious gods whose name is Keeteen or Keidin. Any action of disrespect to these gods was retaliated with death) and the symbol of the god of Inshushinak (the god of Shush and Haft Tappeh, the god of the dead and eternal life and the most powerful god of Elamites) (3). Snake's life inside the soil and cemeteries made this animal appear to the ancient people to be the preserver of soil and whatever is under the soil. They regarded the snake as the guard of the world of the dead or the messenger between this world and the other world (Salehi, 2004: 172). Perhaps one of the reasons for the attribution of a snake to the god of Ishushinak by Elamites was the lifestyle of the snake inside the dust and cemeteries which had made it the symbol of Keeteen the god of the dead.

The reflection of the ideas of Elamites regarding the snake in the design of their furniture can be seen in the following way:

1- Since snake constitutes the most important religious motifs of the Elamites, furniture with snake motifs were used in Elamite civilization's religious ceremonies and had no other function.

2- The relation of snake with creation, life, and fertility in the furniture design can be seen on the small clay table which dates back to the third millennium $\mathrm{BC}$ a specific item for religious rituals (Image 2). On the table, there are images of two snakes crawling around a central circle with a flower of ten petals. The image of a flower with twelve petals can be a symbol of the sun and the circles around the table would refer to the celestial bodies rotating around the sun. The presence of snakes can suggest the concept of creation, life, and fertility. The other probability is that the flower with 12 petals is a symbol of a goddess that snakes are crawling around it in order to protect it. 
3- Some scholars have considered snake to be a symbol of the god of effervescent and springy waters in Elamite civilization. The relationship between snake, water and furniture design can be seen in the special table used in religious ceremonies that dates back to 1200 to 1300 BC (Images 3 and 4). Five goddesses carrying a cup in their hands from which underground waters seem to have bubbled out constitute the legs of the table. The existence of two giant snakes on two sides of the table is an expression of the belief of Elamites in snake as the god of the effervescent waters.
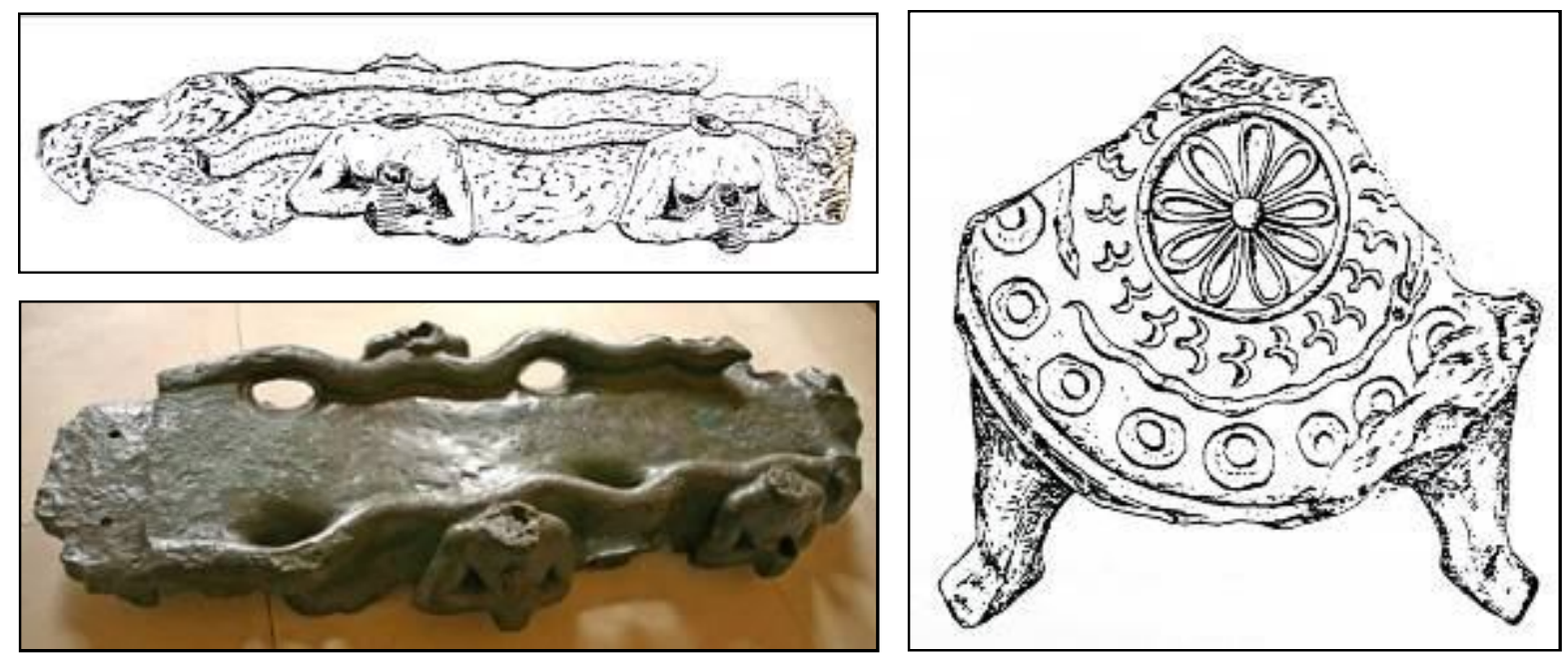

Image 2. Clay Table special for religious ceremony dating back to middle third millennium BC (sources: Pelasaeedi, 2002: 190)

Image 3. Bronze Tabke special for religious ceremony dating back to 1200 to 1300 BC (source: Pelasaeedi, 2002: 192).

Image 4- Bronze Tabke special for religious ceremony dating back to 1200 to $1300 \mathrm{BC}$ source: www.arthistory.upenn.edu

4- We can identify a relationship between the furniture, snake, and god of Inshushinak or other Elamite gods in the snake-like thrones which were used in religious and public ceremonies. The content of seals and reliefs suggests that the use of a snake-like throne is itself an emphasis on the presence of God on the scene. In Elamite thrones with animal images, snake is the most important and dominant animal form. Elamites used the image of snake in simple natural form in order to support their own God. There are also images of a serpent (snake with horn and cat-like snout) and snake God (a combination of god and man). These all endorse the sacred aspect of this reptile among Elamites. They are used in the design of the thrones of gods. In these thrones which were exclusively designed for gods, the coiled snake was the seat and sometimes the head of the snake constituted the splat. It is noteworthy that the throne with a coiled snake figure is an invention of the Elamites. An example of these thrones can be found in the first series of the memorial stone of Ontash Gal that includes four series of varied items and dates back to 1300 BC. In the first series, the god of Inshushinak is sitting on a throne with a coiled snake with the king before itself.

The other example of this throne is available in the Elamite Koorangoon Relief while (K)Humban, the god of heavens or in the words of Dr. Mehrdad Bahar the god of mountain that brings water, is sitting on it. Dr. Mehrdad Bahar believes that this relief expresses the importance of the water in the eyes of Elamites. He argues that the throne of god in this relief is of a snake form because snake is a symbol of divine bounty, preservation, and defense (Bahar, 2002: 545). 

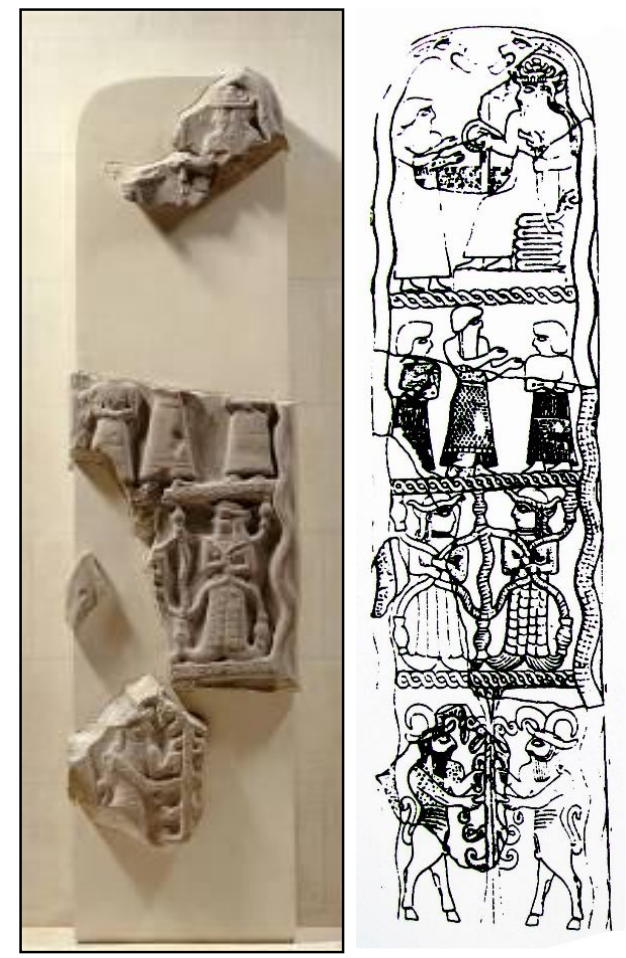

Image 5. Ontash Gal Memorial Stone dating back to $1300 \mathrm{BC}$, at the first series the god of Inshushinak is sitting on a throne with a coiled serpent (source: Pelasaeedi, 2002: 369).

Image 6. Remenants of Ontash Gal Memorial Stone in Louvre Museum) (Soure:www.louvre.fr ).

5- As previously mentioned, Elamites considered snake to be a shield against the diabolic forces and used the snake motif as a symbol of preservation and guard against Satan on their containers and gates. The relationship between furniture and snake figure as the guard on Elamite thrones is understandable. Elamites for protection and support of their gods made use of snake motifs in their thrones. In a statue of a god dating back to the second millennium BC a god is sitting on a coiled snake-like throne and on the left side of it the throat of another snake is at its hand. On the splat of the throne, three simple snakes can be seen as the guards of god which are crawling upward from the down (Images 9 and 10).
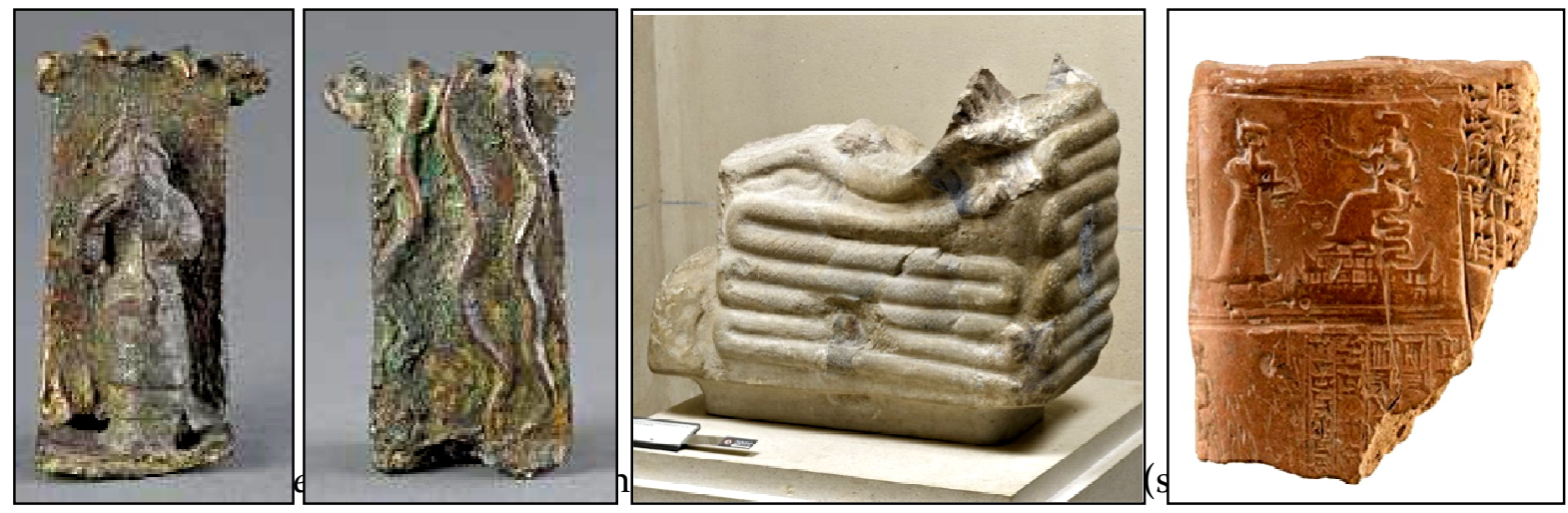

Image 8. God throne statue with three coiled serpents on its sides (source: ibid)

Images 9 and 10. Bronze statue of god throne with a seat in the form of a simple coiled snake and three simple snakes on its splat (source: ibid) 


\section{A Review of Lion Motif in Elamite Furniture Design}

Among the motifs used in the design of Iranian furniture, lion is one of the most ancient and comprehensive ones of them the first manifestation of its application in the design of Iranian furniture can be seen in Elamite civilization. Although furniture with lion motif has been lesser used in the design of Elamite furniture as compared to the snake motif, we are still witnessing the use of this motif in the design of this civilization's furniture from the Third Millennium BC to the First Millennium BC. Elamites (due to the brutish nature of lion) considered lion along with gods and goddesses to be the guard and shield against the evil and the symbol of Leo constellation. The reflection of the ideas of Elamites concerning lion can be seen in their design of furniture:
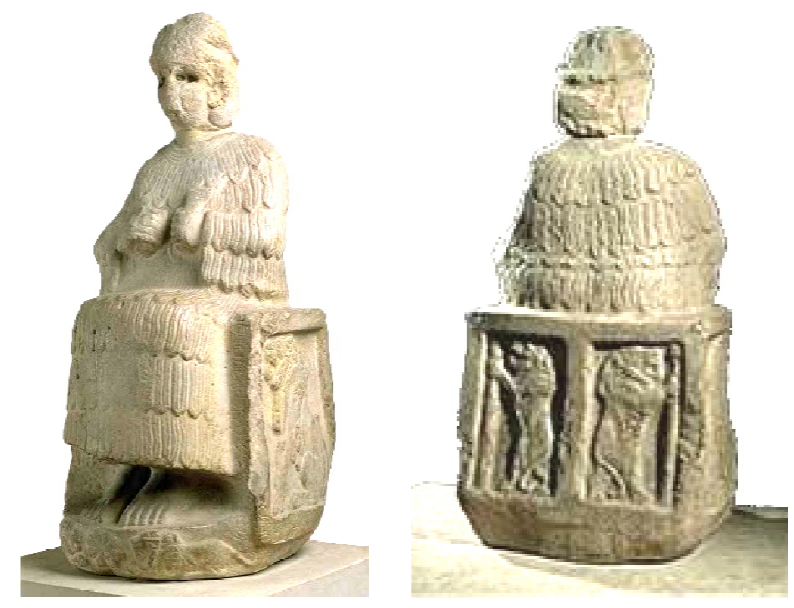

Images 11 and 12. Statue of Narudni Goddess with Ornamentations of Lion on the Throne's Body (Source: ibid).

1- It was noted that Elamites considered lion to be an associate of the gods and goddesses. According to the civilizations of the ancient world, nature, earth and many other phenomena are female. These female phenomena were reified in the form of the great goddess, mother goddess and other titles. These goddesses were associated with animals among which one can refer to lion. Lion is the symbol of the fertility of the earth, death, and life and it was associated with the goddesses of the ancient world like Ishtar in Mesopotamia, Ashi or Art in Iran, Dorga in India and so on (Khani, 2002: 6). In Elamite civilization, lion was always the Narvandi goddess (Koch, 2003: 40). Narundi goddess was the goddess of triumph for the Elamites and had a specific situation among them. King Kotik Inshushinak built a temple in Shush with statues and tablets and devoted them to it. Moreover, ordinary people, as the name of Elamite women suggests, were interested in the female god. The female name "Narundi-ummi" means "Narundi is my mother" and this clearly shows the motherly state of Narundi in people's belief (Hinse, 2008: 59). Thus, Narundi was a goddess for triumph and guarding the rights of the worshippers and taking care of its followers.

The relationship of lion with Narundi goddess in the design of Elamite furniture can be seen in the limy statue of this goddess. On the limy statue of this goddess (images 11 and 12) (dating back to $2250 \mathrm{BC}$ ) in Akkadian language, the donator of this statue (King Kotik Inshushinak) has resorted to this goddess in the following words: "Listen to my prayer! Guard my rights and protect them!" In this statue, Narundi is seen with a fringed skirt and a palm branch in one of her hands while carrying a cup with another on a throne decorated with six lions (two lions on both sides, two lions on the step under the feet of the goddess and two lions with spears at their hands at the backside of the throne). The lions which are carved on the splat are the guards and standing sentinel over with the spears at hand (Hinse, 2008: 59). 
Another example of this relationship can be found in a cylindrical seal (dating back to $2400 \mathrm{BC}$ ) that shows the activity of the goddesses in two series (Image 13). In this seal, we see a goddess which is sitting at the backside of the throne in the form of a lion and two nude servants with palm branches and fanning Narundi. The goddess sitting on the lion's back can be considered as Narundi goddess and it is similar to the limy statue of the goddess from this perspective (Majidzadeh, 1991: 70).

2- It is noted that Elamites considered lion to be the guard of temples due to its ferocity. The entrance of Elamite temples guarded by statues of lion, ox and a type of dog. There was no need for giant statues because only their Keeteen or mysterious power is sufficient for guarding the temple (Hinse, 2008: 65).

The relationship between lion with the protection and guarding in the furniture design is revealed in the restoration of the tiles of the table of gifts on a wall in a temple in Shush (Image 14). In the reconstruction of these tiles, we see several series of animals like Griffin, lions, and horse which guard the life tree two by two (Elamites considered lion to be the guard of life tree which in mythical approaches is depicted as a subtle tree the fruit of which leads to eternal life and deathlessness and lies at the middle of the world. This tree sometimes can be found among two animals like griffin, lion and wild goat as its guards. This tree is a symbol of horrible sacred force for picking its fruit we should fight the animals guarding it) (Kazempur and Abeddoost, 20o8: 104).

3- Elamites considered lion to be the shield against evil and diabolic spirits. Thus, the lion motif in objects, donations or weapons seems to have had a role like a spell and an icon and protected its owner against the diabolic spirits (Kazempur and Abedoost, 2008: 106).

In a relief from Shush in which a princess is shown while she is spinning and a servant is fanning her. We can find the relationship of lion as the shield against the evil and diabolic spirits in furniture design (Image 15). In this relief, there is a lion's paw that constitutes the basis of the throne on which the woman is sitting and also a table that is visible before the woman. Another example of this relationship can be seen on the arm support which is decorated by a lion's head.

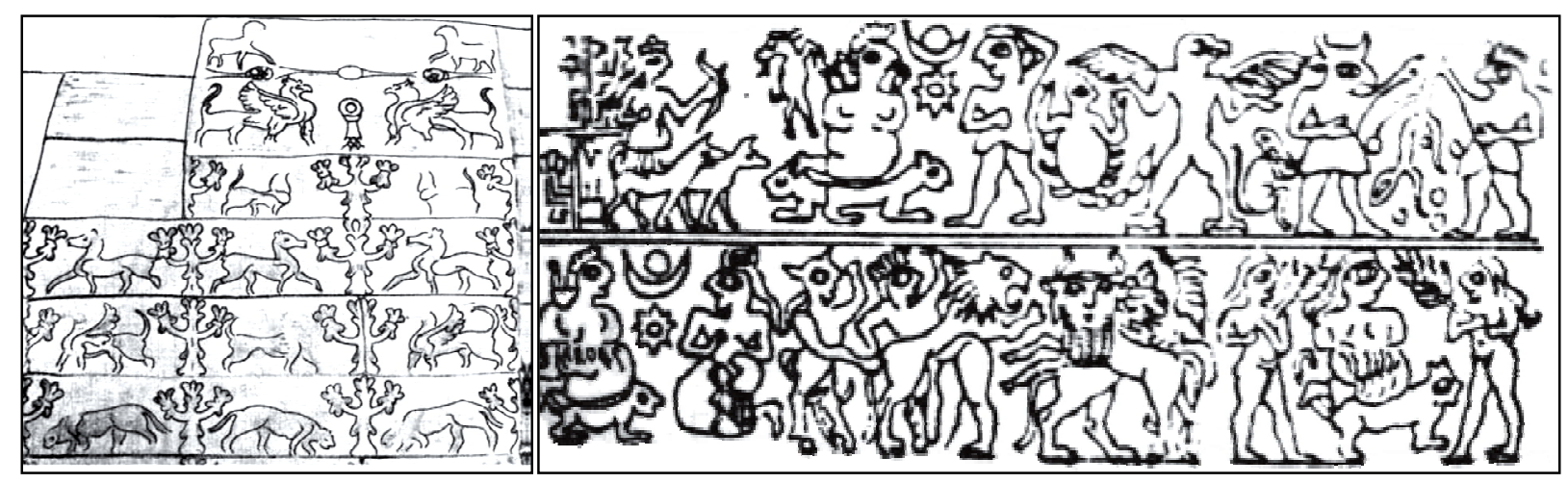

Image 13. Cylindrical seal (dating back to 2400 BC), Narundi Goddess sitting on a throne in the form of a lion (source: Kazempur and Abeddoost, 2008: 105).

Image 14. Tiles of gifts table (dating back to $7^{\text {th }}$ and $8^{\text {th }}$ centuries $\mathrm{BC}$ ), Lions guarding the life tree (source: Kazempur and Abddoost, 2008: 105). 


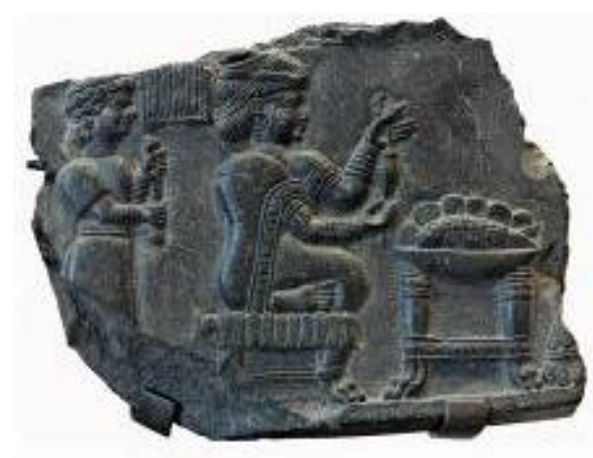

Image 15. Relief of spinning lady, throne and table with lion paws as the feet (source: www.louvre.fr)

\section{A Review of Wild goat Motif in Elamite Furniture Design}

Among other motifs used in the design of Elamite furniture, one can refer to the wild goat. This motif in Iranian furniture design was used in third and second millennia BC in Elamite civilization. Wild goat is the national animal of Persia. In Shush and Elam, wild goat was related to the god of water and the theme of water seeking, affluence and cultivation (in the eyes of Elamites there was a relationship between the crescent and recurved horns of ibex and since the moon was a symbol of rain and humidity from time immemorial, the wild goat was considered to be related with the rain and water. In numerous works from this era we see the ibex to be associated with water) (Masoomi, 1970: 183). Reflection of the ideas of Elamites concerning ibex in the design of their furniture can be seen as follows:

1- The relationship of the wild goat with the god of water and the theme of water seeking in the design of Elamite furniture can be seen in a seal that dates back to the second millennium in Shush. In the right side of this tablet seal is scribed in four vertical columns: "Limulu, the messenger, the son of Ishmani, the servant of A E". Anki the god of reason, spell and the archetype of water for Sumeris and it is very likely that A E or Anki and its animal symbols to have been transferred from Mesopotamia into Elam. The worship of water in Mesopotamia began from the third millennium BC (Mehrafarin, 2001: 285). The manifestations of this worship are reflected in various forms on cylindrical seals. These manifestations consist of:

A- A god with a long dress and horned hat is sitting on a throne in the form of a wild goat or deer.

B- God has put its legs on a hybrid animal the upper body of which is goat while the lower part of its body is fish.

C- Another hybrid creature half of the body of whom is human while the other half is in the form of water waves is often under the feet of the throne of God.

D- A merman or mermaid is always around these images.

In this seal, the god of water is sitting on an ibex like a throne. Here the feet are the legs, the body is the seat and the head is the backside of the throne. The creature which has been used by the god as a stool is a goat-fish and a hybrid creature half of its body is human while the other half is in the form of water waves. Under the legs of the throne god lies (Image 16). In another seal dating back to the third millennium from Shush, we see a similar scene. Here again, the god of water wears a long dress with a horned helmet sits on a goat-like throne and stretches its legs on a goat-fish. There is also a god under the throne in the form of a hybrid creature half of the body of 
which is human while the other half is in the form of water waves under the legs of the throne of god.

Another relationship between goat and water can be seen in a seal dating back to the third millennium from Chughamish. In this seal, the scene of the voyage of the emperor along with his associates with a vessel which is the symbol of water has been depicted. The emperor is sitting on a throne in the form of a goat. Here the feet are legs and the body is the seat and the throne lacks any backside.
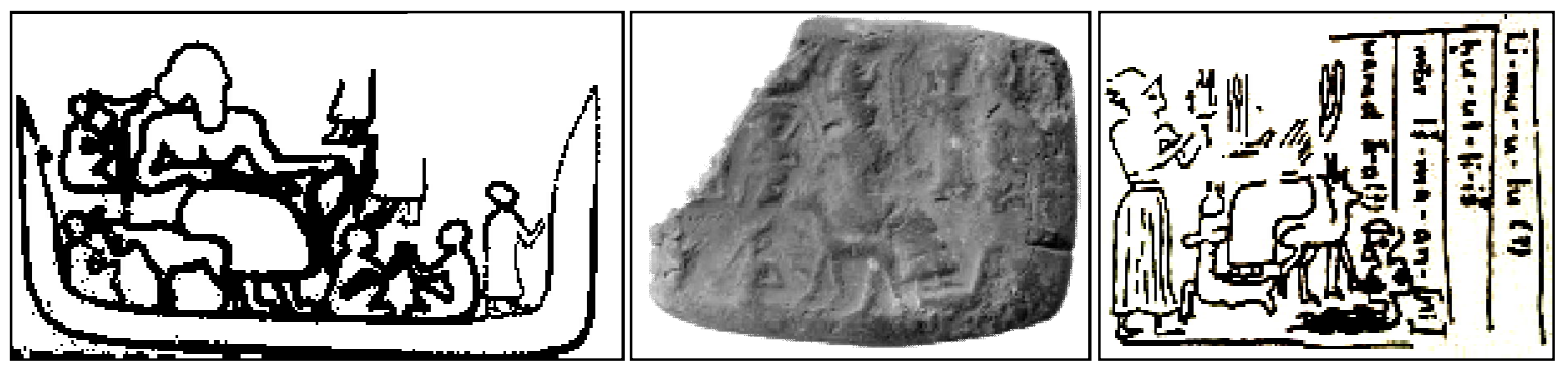

Image 16. Throne in the form of a goat for the god of water (Mehrafarin, 2001: 299).

Image 17. Another throne in the form of a goat for the god of water (source: www.louvre.fr)

Image 18. Emperor's voyage with the vessel, the emperor on a goat-like throne (source: Sajjadi, 2002: 19o).

2- The relationship of goat with the affluence of bounties in a seal dating back to the second millennium BC. This seal shows the scene of offering a sacrifice before the god who is sitting on a throne in goat form with a dagger which is the symbol of sacrifice. What is suggested by the theme of this seal is that the goat motif bespeaks of the affluence in a determinate era. In another seal dating back to the third millennium BC, we see a man with two snakes on his shoulders who sits on a goat-like throne. This throne lacks any ornament and has been drawn with bold lines. The theme of this seal refers to affluence.

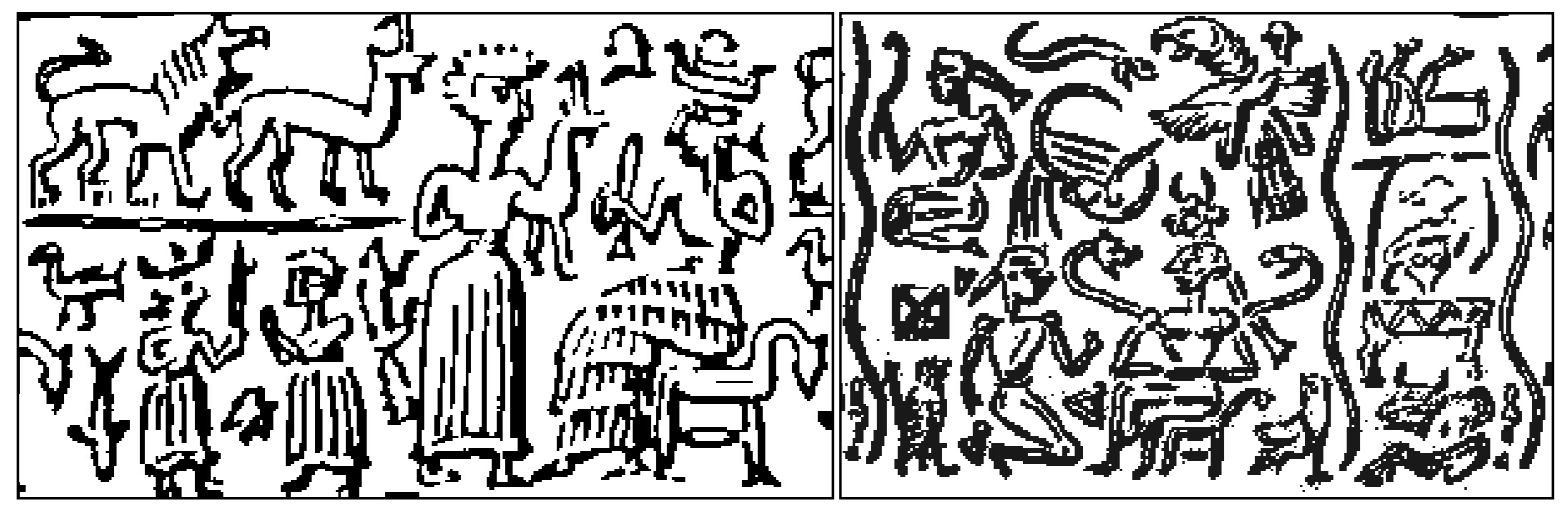

Image 19. Cylindrical seal dating back to third millennium BC presents a person with two snakes on his shoulders sitting on a goat-like throne (source, Sajjadi, 2002: 191).

Image 2o. Cylidrical seal of middle Elam, the god on a throne in the form of a goat (Source: Sajjadi, 2002: 191).

\section{A Review of the Duck Motif in Elamite Furniture Design}

There is only one example of the furniture with the duck motif in the Elamite civilization in Iran. This example is a seal carved on a blue opal that presents the Shilhak-Inshushinak the Elamite king giving a gift to his daughter Baravli with a tablet on the right side that reads as follows: "I, 
Shilhak-Inshushinak, the magnificence of the empire, got this opal stone from Poralish land. I have made it with all precision and presented it to my beloved daughter Baravli". On the left side, Shilhak-Inshushinak is sitting on a chair and has the opal in his hand while his daughter is standing before him (Esfandyari, 1998: 65).

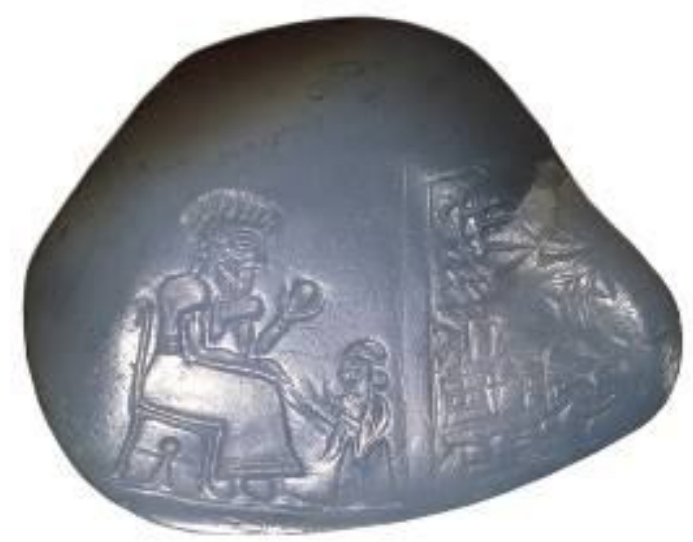

Image 1o. Throne in the form of duck (source: www.britishmuseum.org)

The chair of the king has a back and legs in the form of the head and leg of the duck. In the civilization of Elam, stroke or duck are the symbols of the role of water and the significance of farming. Perhaps the cause of the duck motif use in this place is the flourishing of farming in those times. Because in the time of Shah Shilhak-Inshushinak, the most powerful king of Elam during eight times of military action against Mesopotamia, the territory of Elam was developed towards the Mesopotamian lands. During his reign, the whole valley of Dajleh and Persian Gulf bank and Zagros chain mountains were conquered by Elam and in this way, the ground was prepared for the flourishing of agriculture.

\section{Conclusion:}

Iranian furniture has always been inspired by religious symbols and ideas and Iranian people in every age developed a specific relationship with it. Elamites as the founder of the use of the animal forms and motifs in the design of Iranian furniture have taken advantage of mythical and religious animals mostly snake in the design of furniture. They reflected their ideas concerning this mythical animal in their design of the furniture. Insofar as the relationship between snake, guard against diabolic forces, fertility, underground waters, and gods especially Inshushinak god can be inferred from the design of their furniture. Elamites in addition to snake have also taken advantage of other animal motifs even in lesser degrees like lion, ibex, and duck which are of religious and social import proportionate to their relevant ideas in this regard.

A review of the history of Iranian furniture suggests that the furniture with animal mythical motifs have just been used by the gods, kings, and satraps in their religious rituals and public ceremonies. On such occasions, the aforementioned motifs were used for designing the furniture drawing upon the religious beliefs and social norms. Elamites were not an exception to this. In the time of Elamites, similar motifs were used by gods, kings or the Elamite officials in religious ceremonies and formalities and the highest frequency of these motifs can be seen in the second millennium. 


\section{Endnotes:}

${ }^{\mathrm{i}}$ Behavior and face of a snake with fixed mysterious and fearful eyes in many; in many cultures, snake plays a role as the guard of temples and religious sites. The author by a comparative study of the snake motif in other cultures contends that it is perhaps the type of eyes and face of the snake that led the Elamites to take the snake as the guard and shield against diabolic forces.

${ }^{i i}$ Snake in many civilizations due to its ability to change its skin is the symbol of fertility. It seems that this is why the snake is considered to be the symbol of fertility in Elamite civilization.

${ }^{i i i}$ For more information in this regard see. Sarraf, Mohammad Rahim (1993), Elamite Reliefs, Second Edition, Tehran, Jahad Daneshgahi (Tehran University), p. 74.

\section{Sources:}

Amiet, Pierre. (2005). History of Elam, trans. Shirin Bayani, fourth edition, Tehran, Tehran University Press.

Esfandyari, Azarmidokht. (1998). "History of chair and water lilly in archaeological documents", Journal of Archaeology and History, Year 11, no. 1 and 2.

Bahar, Mehrdad. (2011). From myth to history, edited by Abulqasem Esmaeelpur, seventh edition, Tehran, Cheshmeh Press.

Prada, Idet. (2012). Art of Ancient Persia (Pre-Islamic Civilizations), trans. Yusef Majidzadeh, fourth edition, Tehran, Tehran University Press.

Pelasaeedi, Katayoon. (2002). Snake motif in Elamite Culture and Civilization, MA Thesis in Archaeology, Islamic Azad University of Central Tehran, Mir Damad Graduate Campus.

Taqavi, Tarannom. (2009). Symbolic concept of snake in Iran (Comparison with Neigboring civilizations; Mesopotamia, India, Greece, and Egypt), MA thesis in Art Studies, Tarbyat Modarres University.

Khani, Shahin. (2002). "Prehistoric Animal Lady", Journal of Art, No. 16.

Sajjadi, Ayda. (2002). Elamite thrones from 3000 to 640 BC, MA Thesis in Archaeology, Islamic Azad University of Central Tehran, Mir Damad Graduate Campus.

Sarraf, Mohammad Rahim. (1993). Elamite Reliefs, Second Edition, Tehran, Jahad Daneshgahi.

Salehi, Khosrow. (2004). Snake myths in Iran and World, first edition, Blurin Press.

Kazempur, Ziba, Abeddoost, Hossein. (2008). "Relevant notions of lion symbol in Ancient Persia's art to Sassanid era, A Comparative Study of Mesopotamian Art”, Nakreh, no. 8 and 9.

Koch, Heid Marry. (2003). “Theology and Worshipping in Elam and Achaemenid Iran”, trans. Negin Marvi, Ancient Studies, no. 11.

Majidzadeh, Yusif. (1991). History and Civilization of Elam, First Edition, Tehran, Markaz Nashr Daneshgahi.

Masoomi, Gholamreza. (1970). "Wild goat Motif on Prehistoric Clays", Historical Studies, no. 27.

Mehrafarin, Reza. (2001). "Mythical Motifs in Cylindrical Seals of Elam", Journal of Humanities of University of Sistan and Baluchestan, Special Issue of History and Social Sciences.

Hinse, Walter. (2008). Elam Kingdom, trans. Parviz Rajabi, first edition, Tehran, Nashr Mahi. 